Review

\title{
Antimicrobial efficacy of chlorhexidine as a root canal irrigant: a literature review
}

\author{
Zahed Mohammadi1), Hamid Jafarzadeh²), and Sousan Shalavi³) \\ 1)Iranian Center for Endodontic Research, Shahid Beheshti University of Medical Sciences, Tehran, Iran \\ 2)Dental Research Center, Department of Endodontics, Faculty of Dentistry, \\ Mashhad University of Medical Sciences, Mashhad, Iran \\ ${ }^{3)}$ General Dental Practitioner, Hamedan, Iran
}

(Received December 21, 2013; Accepted March 13, 2014)

\begin{abstract}
Use of an appropriate root canal irrigant is essential during endodontic treatment, due to the complex and unpredictable anatomy of the root canal system and limitations in the mechanical instrumentation techniques used to obtain a clean, bacteria-free canal. Several irrigants, such as sodium hypochlorite, chlorhexidine, hydrogen peroxide, and normal saline, have been proposed as canal system irrigants in endodontic treatment. The widely used endodontic irrigant chlorhexidine is a positively charged lipophilic/hydrophobic molecule that interacts with phospholipids and lipopolysaccharides on the bacterial cell membrane. In endodontics, its mode of antibacterial activity is determined by its concentration $(0.2 \%$ or $2 \%)$. This article reviews findings from available endodontic studies on the antibacterial, antifungal, and antibiofilm activities of chlorhexidine. (J Oral Sci 56, 99-103, 2014)
\end{abstract}

Keywords: antibacterial; antifungal; biofilm; chlorhexidine; endodontics.

\section{Introduction}

Bacteria have a fundamental role in the pathogenesis of pulpoperiapical diseases (1-3). However, elimination of

Correspondence to Dr. Hamid Jafarzadeh, Dental Research Center, Department of Endodontics, Faculty of Dentistry, Mashhad University of Medical Sciences, Vakilabad Blvd, Mashhad, PO Box: 91735-984, Iran

Fax: +98-511-8829500

E-mail: hamid_j365@yahoo.com \& JafarzadehBH@mums.ac.ir

doi.org/10.2334/josnusd.56.99

DN/JST.JSTAGE/josnusd/56.99 bacteria from an infected canal is a difficult process that requires the use of various instrumentation techniques, irrigants, and intracanal medications. Because of the complex and unpredictable anatomy of the canal system, mechanical preparation of the canal is not sufficient to ensure that a canal system is free of bacteria (4). Ex vivo and in vivo evidence indicates that mechanical preparation can leave many areas of the canal walls uninstrumented (5) and that instrumentation alone is unlikely to completely remove microorganisms (6).

Remnant pulp can serve as a nutrient source for remaining bacteria. Tissues left in the canal can also limit the antibacterial effects of irrigants. Agents used for chemical debridement of canals are divided into three categories: irrigants, root canal rinses, and interappointment medicaments.

The effectiveness of mechanical instrumentation of the canal can be improved by supplementation with suitable irrigants, ie, medicated fluids used to wash out a cavity inside the body. The goals of this procedure are mechanical and biological. The effectiveness of irrigation, defined as removal of debris and elimination of bacteria, depends on the diameter of the root canal, the penetration depth of the irrigating needle, irrigation pressure, and the properties of the solution. Several irrigants, such as sodium hypochlorite $(\mathrm{NaOCl})$, chlorhexidine (CHX), hydrogen peroxide $\left(\mathrm{H}_{2} \mathrm{O}_{2}\right)$, and normal saline, have been proposed as endodontic irrigants of the root canal system. Some of these irrigants, such as $\mathrm{NaOCl}$, have proven beneficial properties in canal irrigation (such as antimicrobial action and removal of the smear layer), whereas others have no antimicrobial effects and thus may not be effective irrigants $(7,8)$. $\mathrm{CHX}$ is a widely used endodontic irrigant and medicament that was devel- 
oped in the United Kingdom in the late 1940s (9). The present article will review evidence from studies of the antimicrobial efficacy of $\mathrm{CHX}$ as an endodontic irrigant.

\section{Structure}

CHX $\left(\mathrm{C}_{22} \mathrm{H}_{30} \mathrm{Cl}_{2} \mathrm{~N}_{10}\right)$ is a synthetic material comprising two biguanide groups and two symmetric 4-cholorophenyl rings, connected by a hexamethylene chain (10).

\section{Mechanism of action}

CHX is a hydrophobic and lipophilic molecule that interacts with lipopolysaccharides and phospholipids on the bacterial cell membrane (11). The beneficial effects of CHX are due to the interaction of its positive charge with the negatively charged phosphate on bacteria cell walls (12) and its ability to alter the osmotic equilibrium of bacteria cells. This can increase cell wall permeability and allow CHX to penetrate the cell. At high concentrations $(\geq 2 \%)$, CHX is a bactericide, as it causes precipitation of cytoplasmic contents; at a lower concentration $(0.2 \%)$ it causes phosphorous and potassium to leak out of cell structures (12).

\section{Antibacterial activity}

In an in vitro study, Delany et al. (13) studied the effects of $0.2 \% \mathrm{CHX}$ in infected canals and found that the number of microorganisms was greatly reduced after instrumentation and irrigation. Another in vitro study reported that CHX was the only disinfectant that eliminated Actinomyces israelii compared to calcium hydroxide $\left(\mathrm{Ca}(\mathrm{OH})_{2}\right)$ (14). An in vitro study (15) evaluated the antibacterial properties of $2 \% \mathrm{CHX}$ and $0.2 \% \mathrm{CHX} / 0.2 \%$ cetrimide at $5 \mathrm{~min}$ and $48 \mathrm{~h}$ after infecting canals with Enterococcus faecalis: 2\% CHX was effective against $E$ faecalis at both time points. Both the $2 \%$ liquid and $2 \%$ gel formulations removed Candida albicans and Staphylococcus aureus within $15 \mathrm{~s}$, and the gel product eliminated $E$. faecalis within $1 \mathrm{~min}(16,17)$. Addition of $2 \% \mathrm{CHX}$ to an endodontic treatment protocol significantly improved root canal disinfection (18). A clinical study (19) showed that $0.12 \% \mathrm{CHX}$ reduced bacteria numbers in infected canal systems.

A clinical trial demonstrated that the antibacterial effects of $\mathrm{CHX}, \mathrm{Ca}(\mathrm{OH})_{2}$, and a combination of $\mathrm{Ca}(\mathrm{OH})_{2}$ and CHX were equivalent (20). Another in vivo study showed that the combination of a $\mathrm{Ca}(\mathrm{OH})_{2}$ slurry and $2 \%$ CHX was as effective as aqueous $\mathrm{Ca}(\mathrm{OH})_{2}(21)$.

Both $2 \% \mathrm{CHX}$ and $\mathrm{NaOCl}$ are effective in reducing the number of bacteria in necrotic teeth and treating periapical pathosis (22).

In an ex vivo study, a combination of $3 \% \mathrm{H}_{2} \mathrm{O}_{2}$ and $\mathrm{CHX}$ was better than $\mathrm{CHX}$ alone and $\mathrm{NaOCl}$ in eliminating bacteria (23). A combination of CHX and $\mathrm{H}_{2} \mathrm{O}_{2}$ killed $E$. faecalis at concentrations lower than those required for each irrigant alone. The reasons for the synergistic effect of $\mathrm{CHX}$ and $\mathrm{H}_{2} \mathrm{O}_{2}$ are unknown; however, exposure of microorganisms to $\mathrm{CHX}$ might increase permeability of bacteria cell walls, thereby allowing $\mathrm{H}_{2} \mathrm{O}_{2}$ to easily penetrate the cell and damage cellular organelles (24).

\section{Antifungal activity}

Vital fungi are present in 1-17\% of infected root canals (25). As compared with canals irrigated with only $\mathrm{NaOCl}$, canals irrigated with a final rinse of $2 \% \mathrm{CHX}$ were free of bacteria significantly more often $(25,26)$.

Using a cylindrical dentin tube model, Sen et al. (27) studied the antifungal effect of $0.12 \% \mathrm{CHX}$ against $C$. albicans and found that $C$. albicans was more resistant to CHX when the smear layer was present than when it was removed. Waltimo et al. (28) showed that $0.5 \%$ CHX killed all C. albicans cells after only $5 \mathrm{~min}$. Another study found that bovine dentin treated with $\mathrm{CHX} /$ zinc oxide (ZO) paste was disinfected after $60 \mathrm{~min}$ (29). An interesting in vitro study (30) found that CHX digluconate was effective against $C$. albicans even when substantially diluted.

\section{Effect on biofilm}

The biofilm concept in endodontics was first discussed in the context of microorganisms on the tips of roots with infected canals $(31,32)$.

Some recent evidence indicates that the resistance of bacteria grown in biofilms is $2-1,000$ times that of the planktonic forms of the same microorganisms (32). Spratt et al. (33) assessed the effectiveness of $0.2 \%$ CHX, $10 \%$ iodine, $2.25 \% \mathrm{NaOCl}$, and phosphate-buffered saline (PBS) against single-species biofilms of some microorganisms and found that $\mathrm{NaOCl}$ and iodine were more effective than $\mathrm{CHX} ; \mathrm{NaOCl}$ and iodine resulted in complete eradication after a $1-\mathrm{h}$ incubation period. In another in vitro study $2 \%$ CHX did not disrupt biofilm (34). Using a novel in vitro testing system, Dunavant et al. (35) showed that $2 \%$ CHX killed $60 \%$ of bacterial cells in E. faecalis biofilms. In contrast, an in vitro study (36) showed that formulations containing $2 \% \mathrm{CHX}$ eliminated most $E$. faecalis biofilms.

An in vitro study of single-species biofilm (37) showed that mechanical agitation improves the antibacterial properties of $2 \% \mathrm{CHX}$. Williamson et al. (38) found that $6 \% \mathrm{NaOCl}$ was significantly more effective than $2 \%$ CHX against a monoculture biofilm of an isolate of $E$. faecalis at 1 and $3 \mathrm{~min}$. Arias-Moliz et al. (39) noted that 
CHX eradicated E. faecalis biofilm after 5 min. Using confocal microscopy, Chavez de Paz et al. (40) assessed the effect of $2.5 \%$ CHX on biofilms of E. faecalis and other species isolated from canals with persistent infections and concluded that the treatment removed only half of biofilm cells. Arias-Moliz et al. (39) found that CHX did not eradicate E. faecalis biofilms at any concentration. A laboratory study showed that microorganisms in nutrient-limited biofilms and mature biofilms are more resistant to a CHX solution than those in young biofilms (41).

A 2\% CHX solution did not improve biofilm dissolution or increase dentin cleaning in comparison with $\mathrm{NaOCl}$ (42). An in vitro study showed that treatment with 2\% CHX for 5 min killed most microorganisms in E. faecalis biofilms (43). DNase I and dextranase may decrease bacteria adhesion to dentin and sensitize bacterial biofilms to $2 \% \mathrm{CHX}$ (44).

\section{Substantivity}

Dentin medicated with CHX acquires antibacterial substantivity. The absorption of positively charged ions released by CHX prevents bacterial colonization on the dentin surface, and the duration of this effect exceeds the period of medicament application (11).

In an in vivo study (45), the substantivity of tetracycline was greater than that of $\mathrm{CHX}$ for 12 days and greater than that of normal saline for 16 days. An in vitro study showed that the antibacterial substantivity of 2\% CHX may persist for 3 days (46). A clinical study found that the substantivity of $2 \%$ CHX persisted for up to 2 days (47). However, other studies noted that $\mathrm{CHX}$ substantivity may persist for 4 (48) to 12 (49) weeks.

The duration of dentin treatment needed to induce substantivity is unknown. While some studies showed that a 5- to 10-min dentin treatment induced substantivity (36,37), another study (38) found that CHX substantivity was related to the capacity of dentin to absorb CHX. Using infected dentinal tubules from cylindrical bovine specimens, Lin et al. (50) showed that microorganisms in all dentin layers were reduced by CHX and were completely eliminated with a CHX slow-release device. Komorowski et al. (51) showed that 7 days was the optimal duration for CHX treatment of dentin.

\section{Combining $\mathrm{CHX}$ with $\mathrm{Ca}(\mathrm{OH})$}

In a study using agar diffusion, the addition of $\mathrm{Ca}(\mathrm{OH})_{2}$ to $0.5 \%$ CHX significantly reduced the antimicrobial effectiveness of CHX. The researchers attributed this effect to deprotonation of CHX, which alters its interaction with microbial surfaces (52). This was confirmed in studies by
Almyroudi et al. (53) and Schäfer and Bössmann (54).

A combination of $2 \% \mathrm{CHX}$ and $\mathrm{Ca}(\mathrm{OH})_{2}$ reduced the antifungal activity of CHX for 1 week (55). However, there was no significant difference between $\mathrm{CHX}$ and the $\mathrm{CHX} / \mathrm{Ca}(\mathrm{OH})_{2}$ combination at 15 days. Using agar diffusion, de Souza-Filho et al. (56) showed that 2\% CHX gel was more effective than a combination of $2 \% \mathrm{CHX}$ and $\mathrm{Ca}(\mathrm{OH})_{2}$.

In contrast, Al-Nazhan and Al-Obaida (57) studied the effectiveness of $2 \% \mathrm{CHX}$ combined with $\mathrm{Ca}(\mathrm{OH})_{2}$ against C. albicans and noted additive benefits when combining these agents. Another study revealed that a mixture of $\mathrm{CHX}$ and $\mathrm{Ca}(\mathrm{OH})_{2}$ was more effective than $\mathrm{Ca}(\mathrm{OH})_{2}$ against $C$. albicans and $E$. faecalis (58). A clinical study (59) found no significant difference between CHX and $\mathrm{CHX} / \mathrm{Ca}(\mathrm{OH})_{2}$ in effectiveness against anaerobic microorganisms.

\section{Clinical implications and concerns}

Although CHX is useful as a final irrigant, its use as a main endodontic irrigant of the canal is not advised due to its inability to dissolve necrotic remnants $(60,61)$ and to the fact that it is less effective against gram-negative microorganisms than against gram-positive microorganisms $(9,62,63)$. The possibility of anaphylactic reactions due to CHX is another concern (64). Acute allergic reactions such as Quincke edema and urticaria have been reported after skin exposure to CHX $(65,66)$. The potential risks of $\mathrm{CHX}$ should be assessed in future research.

In endodontics, $\mathrm{CHX}$ is used in two concentrations $(0.2 \%$ and $2 \%)$, and its mode of antibacterial activity is related to concentration. CHX is bacteriostatic at a concentration of $0.2 \%$ and bactericidal at a concentration of $2 \%$. Although studies of the antibacterial effectiveness of $\mathrm{NaOCl}$ and $\mathrm{CHX}$ have revealed some differences between these agents, their antibacterial effects ex vivo (in infected dentin) and in vivo (in the canal) appear to be similar when they are used at identical concentrations. Furthermore, although CHX has a strong antifungal effect, its effectiveness was considerably less than that of $\mathrm{NaOCl}$. CHX is considered an effective agent against microbial biofilms; however, $\mathrm{NaOCl}$ is the only endodontic irrigant that can disrupt biofilm. The principal challenge that prevents the use of $\mathrm{CHX}$ as a routine irrigant in endodontics is its lack of tissue solubility during chemomechanical preparation (67). Nevertheless, the substantivity of CHX is a major advantage and makes it an ideal irrigant for final rinsing of the canal.

\section{References}

1. Kakehashi S, Stanley HR, Fitzgerald RJ (1965) The effects of 
surgical exposures of dental pulps in germ-free and conventional laboratory rats. Oral Surg Oral Med Oral Pathol 20, 340-349.

2. Sundqvist G (1976) Bacteriological studies of necrotic dental pulps. Umea University Odontological Dissertations 7, 5-89.

3. Möller AJ, Fabricius L, Dahlén G, Ohman AE, Heyden G (1981) Influence on periapical tissues of indigenous oral bacteria and necrotic pulp tissue in monkeys. Scand J Dent Res 89, 475-484.

4. Hess W (1925) Anatomy of root canals of the teeth of the permanent dentition, part 1. William Wood, New York, 1-39.

5. Peters OA, Laib A, Göhring TN, Barbakow F (2001) Changes in root canal geometry after preparation assessed by highresolution computed tomography. J Endod 27, 1-6.

6. Byström A, Sundqvist G (1981) Bacteriologic evaluation of the efficacy of mechanical root canal instrumentation in endodontic therapy. Scand J Dent Res 89, 321-328.

7. Hargreaves KM, Cohen S (2011) Cohen's pathways of the pulp. 10th ed, Mosby Elsevier, St Louis, 312-314.

8. Bidar M, Hooshiar S, Naderinasab M, Moazzami M, Orafaee $\mathrm{H}$, Naghavi $\mathrm{N}$ et al. (2012) Comparative study of the antimicrobial effect of three irrigant solutions (chlorhexidine, sodium hypochlorite and chlorhexidinated MUMS). J Contemp Dent Pract 13, 436-439.

9. Davies GE, Francis J, Martin AR, Rose FL, Swain G (1954) 1:6-Di-4'-chlorophenyldiguanidohexane (hibitane); laboratory investigation of a new antibacterial agent of high potency. Br J Pharmacol Chemother 9, 192-196.

10. Greenstein G, Berman C, Jaffin R (1986) Chlorhexidine: an adjunct to periodontal therapy. J Periodontol 57, 370-377.

11. Athanassiadis B, Abbott PV, Walsh LJ (2007) The use of calcium hydroxide, antibiotics and biocides as antimicrobial medicaments in endodontics. Aust Dent J 52, S64-82.

12. Gomes BP, Ferraz CC, Vianna ME, Berber VB, Teixeira FB, Souza-Filho FJ (2001) In vitro antimicrobial activity of several concentrations of sodium hypochlorite and chlorhexidine gluconate in the elimination of Enterococcus faecalis. Int Endod J 34, 424-428.

13. Delany GM, Patterson SS, Miller CH, Newton CW (1982) The effect of chlorhexidine gluconate irrigation on the root canal flora of freshly extracted necrotic teeth. Oral Surg Oral Med Oral Pathol 53, 518-523.

14. Basson NJ, Tait CM (2001) Effectiveness of three root canal medicaments to eliminate Actinomyces israelii from infected dentinal tubules in vitro. SADJ 56, 499-501.

15. Onçağ O, Hoşgör M, Hilmioğlu S, Zekioğlu O, Eronat C, Burhanoğlu D (2003) Comparison of antibacterial and toxic effects of various root canal irrigants. Int Endod J 36, 423-432.

16. Gomes BPFA, Souza SFC, Ferraz CCR, Teixeira FB, Zaia AA, Valdrighi L et al. (2003) Effectiveness of 2\% chlorhexidine gel and calcium hydroxide against Enterococcus faecalis in bovine root dentine in vitro. Int Endod J 36, 267-275.

17. Vianna ME, Gomes BP, Berber VB, Zaia AA, Ferraz CC, de Souza-Filho FJ (2004) In vitro evaluation of the antimicrobial activity of chlorhexidine and sodium hypochlorite. Oral Surg
Oral Med Oral Pathol Oral Radiol Endod 97, 79-84.

18. Zamany A, Safavi K, Spångberg LS (2003) The effect of chlorhexidine as an endodontic disinfectant. Oral Surg Oral Med Oral Pathol Oral Radiol Endod 96, 578-581.

19. Siqueira JF Jr, Rôças IN, Paiva SS, Guimarães-Pinto T, Magalhães KM, Lima KC (2007) Bacteriologic investigation of the effects of sodium hypochlorite and chlorhexidine during the endodontic treatment of teeth with apical periodontitis. Oral Surg Oral Med Oral Pathol Oral Radiol Endod 104, 122-130.

20. Manzur A, González AM, Pozos A, Silva-Herzog D, Friedman S (2007) Bacterial quantification in teeth with apical periodontitis related to instrumentation and different intracanal medications: a randomized clinical trial. J Endod 33, 114-118.

21. Zerella JA, Fouad AF, Spångberg LS (2005) Effectiveness of a calcium hydroxide and chlorhexidine digluconate mixture as disinfectant during retreatment of failed endodontic cases. Oral Surg Oral Med Oral Pathol Oral Radiol Endod 100, 756-761.

22. Ercan E, Dalli M, Dülgergil CT (2006) In vitro assessment of the effectiveness of chlorhexidine gel and calcium hydroxide paste with chlorhexidine against Enterococcus faecalis and Candida albicans. Oral Surg Oral Med Oral Pathol Oral Radiol Endod 102, e27-31.

23. Heling I, Chandler NP (1998) Antimicrobial effect of irrigant combinations within dentinal tubules. Int Endod J 31, 8-14.

24. Steinberg D, Heling I, Daniel I, Ginsburg I (1999) Antibacterial synergistic effect of chlorhexidine and hydrogen peroxide against Streptococcus sobrinus, Streptococcus faecalis and Staphylococcus aureus. J Oral Rehabil 26, 151-156.

25. Waltimo TM, Haapasalo M, Zehnder M, Meyer J (2004) Clinical aspects related to endodontic yeast infections. Endod Topics 9, 66-78.

26. Siqueira JF Jr, Sen BH (2004) Fungi in endodontic infections. Oral Surg Oral Med Oral Pathol Oral Radiol Endod 97, 632-641.

27. Sen BH, Safavi KE, Spångberg LS (1999) Antifungal effects of sodium hypochlorite and chlorhexidine in root canals. J Endod 25, 235-238.

28. Waltimo TM, Ørstavik D, Sirén EK, Haapasalo MP (1999) In vitro susceptibility of Candida albicans to four disinfectants and their combinations. Int Endod J 32, 421-429.

29. Siqueira JF Jr, Rôças IN, Magalhães FA, de Uzeda M (2001) Antifungal effects of endodontic medicaments. Aust Endod J 27, 112-114.

30. Ferguson JW, Hatton JF, Gillespie MJ (2002) Effectiveness of intracanal irrigants and medications against the yeast Candida albicans. J Endod 28, 68-71.

31. Bowden GH, Hamilton IR (1998) Survival of oral bacteria. Crit Rev Oral Biol Med 9, 54-85.

32. Svensäter G, Bergenholtz G (2004) Biofilms in endodontic infections. Endod Topics 9, 27-36.

33. Spratt DA, Pratten J, Wilson M, Gulabivala K (2001) An in vitro evaluation of the antimicrobial efficacy of irrigants on biofilms of root canal isolates. Int Endod J 34, 300-307. 
34. Clegg MS, Vertucci FJ, Walker C, Belanger M, Britto LR (2006) The effect of exposure to irrigant solutions on apical dentin biofilms in vitro. J Endod 32, 434-437.

35. Dunavant TR, Regan JD, Glickman GN, Solomon ES, Honeyman AL (2006) Comparative evaluation of endodontic irrigants against Enterococcus faecalis biofilms. J Endod 32, 527-531.

36. Lima KC, Fava LR, Siqueira JF Jr (2001) Susceptibilities of Enterococcus faecalis biofilms to some antimicrobial medications. J Endod 27, 616-619.

37. Sena NT, Gomes BP, Vianna ME, Berber VB, Zaia AA, Ferraz $\mathrm{CC}$ et al. (2006) In vitro antimicrobial activity of sodium hypochlorite and chlorhexidine against selected single-specis biofilms. Int Endod J 39, 878-885.

38. Williamson AE, Cardon JW, Drake DR (2009) Antimicrobial susceptibility of monoculture biofilms of a clinical isolate of Enterococcus faecalis. J Endod 35, 95-97.

39. Arias-Moliz MT, Ferrer-Luque CM, Espigares-García M, Baca P (2009) Enterococcus faecalis biofilms eradication by root canal irrigants. J Endod 35, 711-714.

40. Chávez de Paz LE, Bergenholtz G, Svensäter G (2010) The effects of antimicrobials on endodontic biofilm bacteria. $\mathrm{J}$ Endod 36, 70-77.

41. Shen Y, Stojicic S, Haapasalo M (2011) Antimicrobial efficacy of chlorhexidine against bacteria in biofilms at different stages of development. J Endod 37, 657-661.

42. Del Carpio-Perochena AE, Bramante CM, Duarte MA, Cavenago BC, Villas-Boas MH, Graeff MS et al. (2011) Biofilm dissolution and cleaning ability of different irrigant solutions on intraorally infected dentin. J Endod 37, 11341138.

43. Du T, Ma J, Yang P, Xiong Z, Lu X, Cao Y (2012) Evaluation of antibacterial effects by atmospheric pressure nonequilibrium plasmas against Enterococcus faecalis biofilms in vitro. J Endod 38, 545-549.

44. Li W, Liu H, Xu Q (2012) Extracellular dextran and DNA affect formation of Enterococcus faecalis biofilms and their susceptibility to 2\% chlorhexidine. J Endod 38, 894-898.

45. Stabholz A, Kettering J, Aprecio R, Zimmerman G, Baker PJ, Wikesjö UM (1993) Retention of antimicrobial activity by human root surfaces after in situ subgingival irrigation with tetracycline $\mathrm{HCl}$ or chlorhexidine. J Periodontol 64, 137-141.

46. White RR, Hays GL, Janer LR (1997) Residual antimicrobial activity after canal irrigation with chlorhexidine. J Endod 23, 229-231.

47. Leonardo MR, Tanomaru-Filho M, Silva LAB, Nelson-Filho P, Bonifácio KC, Ito IY (1999) In vivo antimicrobial activity of $2 \%$ chlorhexidine used as a root canal irrigating solution. $\mathrm{J}$ Endod 25, 167-171.

48. Khademi AA, Mohammadi Z, Havaee A (2006) Evaluation of the antibacterial substantivity of several intra-canal agents. Aust Endod J 32, 112-115.

49. Rosenthal S, Spångberg L, Safavi KE (2004) Chlorhexidine substantivity in root canal dentin. Oral Surg Oral Med Oral Pathol Oral Radiol Endod 98, 488-492.

50. Lin S, Zuckerman O, Weiss EI, Mazor Y, Fuss Z (2003) Anti- bacterial efficacy of a new chlorhexidine slow release device to disinfect dentinal tubules. J Endod 29, 416-418.

51. Komorowski R, Grad H, Wu XY, Friedman S (2000) Antimicrobial substantivity of chlorhexidine-treated bovine root dentin. J Endod 26, 315-317.

52. Haenni S, Schmidlin PR, Mueller B, Sener B, Zehnder M (2003) Chemical and antimicrobial properties of calcium hydroxide mixed with irrigating solutions. Int Endod J 36, 100-105.

53. Almyroudi A, Mackenzie D, McHugh S, Saunders WP (2002) The effectiveness of various disinfectants used as endodontic intracanal medications: an in vitro study. J Endod 28, 163-167.

54. Schäfer E, Bössmann K (2005) Antimicrobial efficacy of chlorhexidine and two calcium hydroxide formulations against Enterococcus faecalis. J Endod 31, 53-56.

55. Ercan E, Ozekinci T, Atakul F, Gül K (2004) Antibacterial activity of $2 \%$ chlorhexidine gluconate and $5.25 \%$ sodium hypochlorite in infected root canal: in vivo study. J Endod 30, 84-87.

56. de Souza-Filho FJ, Soares Ade J, Vianna ME, Zaia AA, Ferraz CC, Gomes BP (2008) Antimicrobial effect and pH of chlorhexidine gel and calcium hydroxide alone and associated with other materials. Braz Dent J 19, 28-33.

57. Al-Nazhan S, Al-Obaida M (2008) Effectiveness of a $2 \%$ chlorhexidine solution mixed with calcium hydroxide against Candida albicans. Aust Endod J 34, 133-135.

58. Turk BT, Sen BH, Ozturk T (2009) In vitro antimicrobial activity of calcium hydroxide mixed with different vehicles against Enterococcus faecalis and Candida albicans. Oral Surg Oral Med Oral Pathol Oral Radiol Endod 108, 297-301.

59. Sinha N, Patil S, Dodwad, PK, Patil AC, Singh B (2013) Evaluation of the antimicrobial efficacy of calcium hydroxide paste, chlorhexidine gel, and a combination of both as intracanal medicament: an in vivo comparative study. J Conserv Dent 16, 65-70.

60. Calişkan MK, Türkün M, Alper S (1994) Allergy to sodium hypochlorite during root canal therapy: a case report. Int Endod J 27, 163-167.

61. Zehnder M (2006) Root canal irrigants. J Endod 32, 389-398.

62. Hennessey TD (1973) Some antibacterial properties of chlorhexidine. J Periodontal Res 8, Suppl 12, 61-67.

63. Emilson CG (1977) Susceptibility of various microorganisms to chlorhexidine. Scand J Dent Res 85, 255-265.

64. Ohtoshi T, Yamauchi N, Tadokoro K, Miyachi S, Suzuki S, Miyamoto T et al. (1986) IgE antibody-mediated shock reaction caused by topical application of chlorhexidine. Clin Allergy 16, 155-161.

65. Torricelli R, Wüthrich B (1996) Life-threatening anaphylactic shock due to skin application of chlorhexidine. Clin Exp Allergy 26, 112.

66. Snellman E, Rantanen T (1999) Severe anaphylaxis after a chlorhexidine bath. J Am Acad Dermatol 40, 771-772.

67. Naenni N, Thoma K, Zehnder M (2004) Soft tissue dissolution capacity of currently used and potential endodontic irrigants. J Endod 30, 785-787. 